\title{
Ege Üniversitesi Tip Fakültesi Hastanesi'ne Başvuran Hastalarda Varisella Zoster Virüs Serolojik Test Sonuçlarının Değerlendirilmesi
}

\author{
Münevver KAYIN, Çağla Yııdız ALAGÖZ, Ayşın ZEYTINOĞLU, İmre ALTUĞLU \\ Ege Üniversitesi Tip Fakültesi, Tibbi Mikrobiyoloji Anabilim Dalı, İzmir
}

öz

\begin{abstract}
Amaç: Herpesviridae ailesinin bir üyesi olan varisella zoster virüs $(V Z V)$ klinikleri farklı olan varisella (suçiçeği) ve zona (herpes zoster) hastalıklarının etiyolojisinden sorumlu bir virüstür. Doğru tani ile tedavi edilebilir bir enfeksiyon etkeni olan VZV antivirallere duyarlıdır. Serolojik tanıda VZV IgG testi özellikle kişinin etkenle karşılașıp karşılaşmadığını göstermek açısından önemlidir. VZV IgG avidite testleri eski enfeksiyonu ayırt etmede yararlldir, ancak henüz standart değildir. Bu çalıșmanın amacı, rutin tanıda yeni kullanmaya başladı̆̆ımı VZV IgM ve $\operatorname{Ig} G$ enzim immunoassay (EIA) testlerinin ve VZV IgG avidite testinin değerlendirilmesi ve rutin laboratuvar tanı yaklaşımımızı belirlenmesidir.
\end{abstract}

Gereç ve Yöntem: Viroloji laboratuvarına VZV enfeksiyonu ön tanisi ya da viral tarama testleri istemi nedeniyle gelen 5884 VZV IgG ve 3570 VZV IgM testi, VZV IgG testi uyguland.

Bulgular: Üc bin bes yüz yetmis örnekte uygulanan VZV IgM testinin \%7.6'sl (273 örnek) pozitif, \%3.4'ü (120 örnek) sinur de ğer ve $\% 89$ (3177) negatif olarak bulundu. VZV IgG testinde de pozitif, negatif ve sintr değer olarak saptanan hasta saytst sirast ile 4251 (\%72.2), 1363 (\%23.2) ve 270 (\%4.6) idi. Klinik olarak suçiçeği düşünülmeyen ancak VZV IgM testi yinelendiğinde de pozitif çıkan 15 , suçiçe ği kliniği olan ve VZV IgM testi pozitif saptanan iki ve VZV IgM testinin sinır de ğer çıkıp yinelendiğ̈inde pozitif/sinur değer/negatif çlkan 7, toplam 24 örnekte VZV IgG avidite testi çalışldd. Olguların hiçbirinde düşük avidite indeksi saptanmadt. Dört olguda avidite indeksi sinır değer olarak saptandı. Tüm diğer örneklerde avidite indeksi yüksek saptandt.

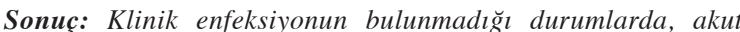
enfeksiyon tanisinin onaykanmasinda, VZV IgM EIA testinin uygun bir test olmadı ̆g düsünülmektedir. VZV IgM testlerinin beklenmedik pozitifliği, izotip antikorların saptanmasındaki standardizasyon eksikliği ile ilgilidir. VZV IgG avidite testi tantda yardımcı de ğildir. Bu çalışmada, VZV IgM ve IgG avidite EIA testlerinin akut enfeksiyon tanısında yararının sinırlı olduğu sonucuna varılmıștır.

\section{ABSTRACT}

Evaluation of Varicella Zoster Virus Serologic Test Results in Patients Admitted to Ege University Faculty of Medicine

Objective: Varicella zoster virus (VZV) is a member of Herpesviridae family and is the responsible etiological agent in two clinical forms as varicella (chicken pox) and zona (herpes zoster). VZV which is the infectious agent of a treatable infection based on accurate diagnosis is susceptible to antivirals. Serologic VZV IgG avidity test is important as VZV Ig G test shows whether the patient has ever acquired this infectionVZV IgG avidity test helps to distinguish recent infection from the past; but is not standardized yet. The aim of this study is to evaluate the VZV IgM and IgG enzyme immunoassay (EIA) tests and VZV IgG avidity test which we have started to use routinely and to determine our routine laboratory diagnostic approach.

Material and Methods: A total of $5884 \mathrm{VZV} \mathrm{IgG} \mathrm{and} 3570 \mathrm{VZV}$ IgM test and VZV IgG avidity test were performed in the patients' sera with the pre-diagnosis of VZV infection or request for viral screening tests.

Results: In this study, of the 3570 samples tested with VZV IgM; $7.6 \%$ (273 samples) were positive, 3.4\% (120 samples) were borderline and $89 \%$ (3177) were negative. The number of VZVIgG positive, negative, and borderline results were 4251 (72.2\%), 1363 $(23.2 \%)$ and $270(4.6 \%)$ respectively. VZV IgG avidity test was performed in a total of 24 samples including 15 samples clinically not thought to be associated with varicella yet repeated VZV IgM test result was positive for the disease, 2 samples of the patients with clinical manifestations of varicella, and 7 samples of the patients whose initial VZV IgM test gave borderline positivity, however when the test was repeated it yielded positive/borderlinel negative result. Lower avidity indices were not detected in any case, In only 4 cases borderline avidity index value was detected., while the remaining samples had high avidity indices.

Conclusion: In conclusion the VZV IgM enzyme immunoassay test is not considered to be a suitable test in the confirmation of the diagnosis of acute infection in the absence of clinical infection . Unexpected positivity in VZV IgM tests is related to the lack of standardization of EIA for the detection of these isotype antibodies. The VZV IgG avidity test has not helped for the diagnosis. The utility of VZV IgM and IgG avidity EIA tests were considered to be limited in diagnosing acute infection.

Keywords: VZV, serology, avidity

Alındığı tarih: 07.02.2017

Kabul tarihi: 21.07 .2017

Yazışma adresi: Münevver Kayın, Ege Üniversitesi Tıp Fakültesi, Tıbbi Mikrobiyoloji Anabilim Dalı, Bornova / İzmir

e-posta: munevver.kayin@outlook.com 


\section{GíRiş}

Herpesviridae ailesinin bir üyesi olan varisella zoster virüs (VZV) klinikleri farklı olan varisella (suçiçeği) ve zona (herpes zoster) hastalıklarının etiyolojisinden sorumlu bir virüstür. VZV, primer enfeksiyonu suçiçeğinden sonra dorsal kök veya kraniyal sinir gangliyonlarında latent hâlde kalır ve hücresel bağışıklığın baskılanması durumunda reaktivasyon görülebi$\operatorname{lir}^{(1,2)}$. Doğru tanı ile tedavi edilebilir bir enfeksiyon etkeni olan VZV antivirallere duyarlıdir. $\mathrm{Bu}$ nedenle VZV enfeksiyonlarında klinik ya da mikrobiyolojik tanı önemlidir. VZV primer enfeksiyonu olan suçiçeği olgularında klinisyenin tanı yaklaşımı genellikle tipik olan kliniğin değerlendirilmesi ile yapılmaktadır. Ancak atipik enfeksiyonun izlendiği immunsuprese olgularda, aşılanmış kişilerde görülen atipik enfeksiyonlarda ve aş1 suşunun neden olabileceği olgular gibi klinik tanının yetersiz kalabileceği durumlarda, VZV'nin mikrobiyolojik tanısı gereklidir $^{(1,2)}$.

Mikrobiyolojik tanı; suçiçeği salgınlarında etkeni belirlemek, fatal seyreden olgularda kesin tanıyı koymak ve özellikle üçüncü basamak sağlık sisteminde, immünsuprese olguların VZV enfeksiyonuna duyarlılığını taramak için (Örn. transplantasyon alıc1/vericilerde vb.) önemlidir. İmmunkompetan hastada tanıda, viremi kısa süreli olduğundan, kanda VZV DNA'nın saptanmas1 sorunludur. VZV enfeksiyonu tanisinda lezyonlardan dev hücrelerin gösterilmesi (Tzanck), Cowdry A inklüzyonlarının belirlenmesi yararlı olabilir. Lezyonda PCR ile genomun saptanması, duyarlılık ve özgüllük açısından en yeğlenen yöntemdir. Serolojik tanıda VZV IgG testi özellikle kişinin etkenle karşılaŞıp karşılaşmadı̆̆ını göstermek açısından önemlidir. Ancak, enfekte tüm hücreyi kullanan rutin IgG testleri doğal geçirilmiş enfeksiyonu saptamada başarılı olmakla birlikte, aşı sonrası antikorları saptamada duyarlılığı düşüktür. Antikor saptanmasında, saflaştırılmış glikoprotein (gpELISA) ve membran antijenlerini floresan yöntemle saptayan (FAMA) testleri de kullanılmaktadır. Aşı1ı ve aşısız olgulara yönelik IgG testleri ile ilgili standardizasyonlar sürmektedir. VZV IgG avidite testleri eski enfeksiyonu ayırt etmede yararlıdır, ancak henüz standart değildir. Suçiçeğinde VZV IgM testinin duyarlılı̆̆ 1 , lezyon örneğinden VZV DNA'nın gösterilmesine göre düşüktür. Duyarlılığın, lezyonda VZV DNA saptanmasına göre düşük olması ve akut enfeksiyonda klinisyenin klinik tablo ile karar verme eğilimi nedeniyle VZV IgM testi rutin kullanımda yerini alamamıştır. Yine, testin yalancı negatifliği ve reenfeksiyon/reaktivasyon ile akut enfeksiyonu ayıramaması testin kullanımını sorunlu hâle getirmektedir. Ancak, döküntüsü olan olgularda VZV IgM pozitifliği varisella tanısı için laboratuvar tanıyı koydurur ${ }^{(1-3)}$.

$\mathrm{Bu}$ çalışmanın amacı, rutin tanıda yeni kullanmaya başladığımız VZV IgM ve IgG enzim immunoassay (EIA) testlerinin ve VZV IgG avidite testinin değerlendirilmesi ve rutin laboratuvar tanı yaklaşımımızı belirlenmesidir.

\section{GEREÇ ve YÖNTEM}

Ege Üniversitesi Tıp Fakültesi, Tıbbi Mikrobiyoloji Anabilim Dalı Viroloji Laboratuvarı'na, VZV enfeksiyonu ön tanısı ya da viral tarama testleri istemi nedeniyle 16.9.2011-31.12.2015 tarihlerinde gelen $5884 \mathrm{VZV}$ IgG ve $3570 \mathrm{VZV}$ IgM testi değerlendirmeye alındı. VZV IgG testi, 3115 kadın ve 2769 erkek, VZV IgM testi ise 1863 kadın ve 1707 erkek olguda uyguland.

Örneklerden Varisella IgG ve Varisella IgM, Diesse (Diagnostica Senese S.p.A, İtalya) kitleri ile Chorus Trio (Diagnostica Senese S.p.A, İtalya) platformunda kit üretici talimatına göre çalışıldı ve indeks değeri 1.1'in üzerindeki olgular pozitif, 0.9'un altındakiler negatif; 0.9-1.1 arasındakiler sınır değer olarak yorumlandı. 
VZV IgG avidite indeksi kat1-faz immunanalitik bir test (ELISA-VIDITEST Anti-VZV IgG and IgG Avidity, Çek Cumhuriyeti) ile belirlendi. Örnekler kit talimatına göre çalışıldı ve "relative avidity index” (RAI) belirlendi. RAI \%40'1n altında ise düşük aviditeli, \%40-60 arasında ise sınır değer, \%60'ın üzerinde ise yüksek aviditeli antikor olarak değerlendirildi.

\section{BULGULAR}

VZV IgG ve VZV IgM testinde yaşlar sırasıyla 1-95 (ort 23.05 yaş) ve 1-95 (22.73 yaş) idi. Üç bin beş yüz yetmiş örnekte uygulanan VZV IgM testinin \%7.6's1 (273 örnek) pozitif, \%3.4'ü (120 örnek) sınır değer ve \%89 (3177) negatif olarak bulundu. VZV IgG testinde de pozitif, negatif ve sınır değer olarak saptanan hasta sayısı sırası ile 4251 (\%72.2), 1363 (\%23.2) ve 270 (\%4.6) idi.

Klinik olarak suçiçeği düşünülmeyen ancak VZV IgM testi yinelendiğinde de pozitif çıkan 15 , suçiçeği kliniği olan ve VZV IgM testi pozitif saptanan iki ve VZV IgM testinin sınır değer çıkıp yinelendiğinde pozitif/sınır değer/negatif çıkan 7, toplam 24 örnekte VZV IgG avidite testi çalışıldı. Olguların hiçbirinde düşük avidite indeksi saptanmad1. Dört olguda avidite indeksi sınır değer olarak saptandı. Tüm diğer örneklerde avidite indeksi yüksek saptandı. IgG avidite indeksi araştırılan örnekler tabloda gösterilmiştir.
VZV IgM pozitif olan olguların 18'inde HSV1+2 IgM bakılmış ve 8'inde eşzamanlı pozitiflik saptanmıştır. Yine, EBV VCA IgM bakılan 167 örneğin 13'ünde ve CMV IgM testi yapılan 208 örneğin 34'ünde VZV IgM ile birlikte pozitiflik saptanmıştır.

\section{TARTIŞMA}

Ülkemizde suçiçeği seroprevalansı çalışmaları ve hastalık komplikasyonlarına bağlı hastane yatışların değerlendirildiği çok merkezli çalışmalar yapılmıştır. Suçiçeği epidemiyolojisi ile ilgili kapsamlı bir çalışmada, dokuz ilde randomize seçilen 4800 kişide, 30 yaş altı olanlarda seroprevalans \%77.8 olarak saptanmıştır ${ }^{(4)}$. İzmir'de aşı öncesi yapılan iki farklı çalışmada, VZV seroprevalans oranları \%71.5 ve \%94.3 olarak belirlenmiştir ${ }^{(5,6)}$. Erzurum'da yapılan bir diğer çalışmada, 30 yaş altı kişilerde seroprevalans \%78, Manisa ilinde yapılan bir diğer çalışmada, 7-15 yaş arasında VZV IgG pozitiflik oranı \%61.6, Ankara'da adolasanlarda yapılan çalışmada, \%55.7 ve Adana'da ilk öğretim ögrrencilerinde $\% 78$ olarak bulunmuştur ${ }^{(7-9)}$. Yine rutin aşılama öncesi dönemde, 0-15 yaş aras1 çocuklarda varisella ile ilgili hospitalizasyon oranı1100.000'de 5.29-6.89 olarak bulunmuştur ${ }^{(10)}$. Türkiye'de Şubat 2013'te çocuklara VZV aşısı uygulanmaya başlanmıştır. Çalışmamızda, yaşları 1 ile 95 arasında değişen (ortalama değer 23.05 yaş) hasta grubunda Varisella IgG olumlu-

Tablo. VZV IgG avidite testi ile indeks araştırılan 24 örneğin sonuçları.

\begin{tabular}{|c|c|c|c|c|}
\hline VZV IgM & Örnek sayısı & Yüksek AI & Sinir AI & Düşük AI \\
\hline $\begin{array}{l}\text { VZV IgM } \\
\text { Birinci çalışma (+) } \\
\text { İkinci çalışma (+) }\end{array}$ & 15 & 14 & $1^{*}$ & 0 \\
\hline Suçiçeği kliniği olan ve VZV IgM (+) & 2 & 0 & 2 & 0 \\
\hline $\begin{array}{l}\text { VZV IgM } \\
\text { Birinci çalışma SD } \\
\text { İkinci çalışma (+)/SD/(-) }\end{array}$ & 7 & 6 & $1 * *$ & 0 \\
\hline Toplam & 24 & 20 & 4 & 0 \\
\hline
\end{tabular}

AI: avidite indeksi; SD: sınır değer; * Kawasaki sendrom tanısı alan bir olgu ** birinci çalışma SD, ikinci çalışma (-) bir olgu 
luğu oranı diğer çalışmalarla uyumlu olarak, $\% 72.2$ olarak bulunmuştur.

VZV enfeksiyonu mikrobiyolojik tanısında fark11 laboratuvar yöntemleri kullanılmaktadır. Hastalığın erken döneminde veziküllerin PCR ile test edilmesinin tanıda duyarlı ve özgül olduğu gösterilmiştir ${ }^{(11,12)}$. Yine oral sürüntü örneklerinin de PCR ile test edilmesi oldukça duyarlı bir yöntem olarak bildirilmektedir(13). Tanıda hücre kültürü ile virüs izolasyonu zaman alıcı olması ve düşük duyarlılığı nedeni ile yaygın olarak kullanılmamaktadır ${ }^{(12)}$. Diğer laboratuvar tanı yöntemlerinden lezyonun direkt floresan antikor yöntemi (DFA) ile incelenmesi hem deneyimli personel gerektirmesi, belirsiz sonuç elde edilebilmesi ve hem de duyarlılık ve özgüllüğüunün düşük olması nedeni ile tanıda çok yararlı olamamaktadır. Serolojik testler ile IgG saptanması kişideki immüniteyi belirlemek açısından kullanılmaktadır. IgG titresinde artışı gözlemlemek açısından iki farklı örnek gerektiğinden akut hastalık tanısında rolü kısıtlıdır. Ek olarak aşı veya daha önce geçirilmiş enfeksiyon nedeni ile antikoru olan hastalarda IgG tiresindeki artış1 göstermek zor olabilmektedir. Primer enfeksiyon sırasında kan alındığı sırada $\operatorname{IgG}$ henüz oluşmamış olabilir ${ }^{(13)}$. VZV aktif enfeksiyonunu desteklemek için pratikte VZV IgM kullanılmakla beraber IgM antikorlarını saptayan pek çok ticari kitin duyarlılıklarının değişken olabildiği, diğer yandan başta HSV olmak üzere diğer herpesvirüslerle yalancı pozitiflik verebildiği belirtilmektedir ${ }^{(14)}$. Bu çalışmada, VZV IgM olumluluğu olan bazı hastalarda eş zamanlı HSV 1+2 IgM, EBV VCA IgM ve CMV IgM saptanması bunun bir göstergesidir. Yine, VZV IgM varlığı, yakın dönem karşılaşmanın göstergesi olabildiği gibi reenfeksiyon ve reaktivasyona da bağlı olabilmektedir ${ }^{(15)}$. IgG avidite testleri primer enfeksiyon (varisella) ve reküren enfeksiyon (zoster) ayrımında yardımcı olabilmekle beraber, deneyim sinırlıdır ${ }^{(16)}$.
Leung ve ark. ${ }^{(13)}$, Varisella enfeksiyonunun tan1sında kullanılan farklı laboratuvar testlerinin değerlendirildiği ve veziküllerden alınan örneğin PCR ile saptanmasının altın standart olarak tanımlandığı çalışmada, vezikülden DFA ile antijen saptanmasının duyarlılığını \% 75, kanda IgM saptanması duyarlılığını \%25, kanda PCR duyarlılı̆̆ını \%42 olarak belirlemiştir. Aynı çalışmada, klinik tanının duyarlılığı aşısızlarda \%100 aş1 ile modifiye olmuş olgularda \%85 olarak saptanmıştır.

$\mathrm{Bu}$ çalışmada, 3570 örnekte uygulanan VZV IgM testinin \%7.6's1 (273 örnek) pozitif, \%3.4'ü (120 örnek) sınır değer olarak bulunmuştur. Pozitif olarak saptanan hastaların ön tanıları incelendiğinde 11 hastanın suçiçeği ve üç hastanın zona zoster (pozitif çıkan 273 örneğin $\% 5.1$ 'i) ön tanısı ile yollandığı gözlenmiştir. Diğer yandan suçiçeği ön tanısı ile yollanan 25 hastanın 14'ünde VZV IgM pozitif olarak saptanmamıştır. VZV enfeksiyonu laboratuvar tanısında, diğer çalışmalarda sözü edilen sorunlar bu çalışmada da gözlenmiş, VZV IgM sonuçlarının klinik hastalık tanısı ile uyum içinde olmadığı ve saptanan IgM olumluluklarının çoğunun primer enfeksiyonun göstergesi olmadığ 1 sonucuna varılmıştır.

Bu çalışmada, VZV IgG avidite testi uygulanan olgu sayısı sınırlıdır. Çalışılan 24 hasta örneğinin yalnızca 4'ünde sınır değer avidite elde edilmiş, geriye kalan örneklerde yüksek avidite saptanmıştır. Sınır değer elde edilen 2 olgu suçiçeği kliniği olan olgulardır. Bu bulgular elde edilen pozitifliklerin çoğunun yakın dönem enfeksiyon olmadığını düşündürmektedir. Diğer yandan klinik bulgusu olan hastalarda yüksek avidite elde edilmesi beklenmeyen bir durum olmuştur. Sinırlı sayıda uygulanan avidite testi sonuçlarının tanıya yararı olmamıştır.

Sonuç olarak, bu çalışmada uygulanan VZV IgM enzim immunoassay testi laboratuvar tan1- 
da klinik hastalığın olmadığı durumlarda akut enfeksiyonu doğrulama için uygun bir test olarak görülmemektedir( ${ }^{(17)}$. Gerekli olmadiğ 1 durumlarda istenen VZV IgM testlerinde beklenmedik IgM pozitiflikleri, bu izotip antikorların saptanmasında enzim immunoassay testlerinin henüz standardize olmaması ile ilgilidir. VZV IgG avidite testi tanıyı netleştirme konusunda yardımcı olmamıştır. Bu çalışmada, VZV IgM ve $\mathrm{IgG}$ avidite EIA testlerinin akut enfeksiyon tanısında yararının sinırlı olduğu sonucuna varılmıştır.

\section{KAYNAKLAR}

1. Rosenthal KS, Pfaller MA. Medical Microbiology, Murray PR, $6^{\text {th }}$ Ed., ABD: Mosby Elsevier, 2008.

2. Whitney RJ. Chickenpox and Herpes Zoster (VaricellaZoster Virus). In Mandell, Douglas, and Bennett's Principles and Practice of Infectious Diseases, $8^{\text {th }}$ Ed., Bennett JE, Dolin R, Blaser MJ (Eds) 2015, Elsevier USA 2015; 1731-8.

3. Centers for Disease Control and Prevention (CDC) Erişim Tarihi:10.01.2017 Available from: http://www. cdc.gov.chickenpox/hcp/lab-tests.html

4. Kanra G, Tezcan S, Badur S, Turkish National Study Team. Varisella seroprevalence in a random sample of the Turkish population. Vaccine 2002; 20:1425-8.

https://doi.org/10.1016/S0264-410X(01)00459-5

5. Kose S, Mandiracioglu A, Senger SS, et al. Seroprevalence of varisella-zoster virus in the prevaccine era: a population-based study in Izmir, Turkey. $J$ Infect Public Health 2013; 6:115-9. https://doi.org/10.1016/j.jiph.2012.10.003

6. KoturogluG,KurugolZ,TurkogluE.Seroepidemiology of varisella-zoster virus and reliability of varisella history in Turkish children, adolescents and adults. Paediatr Perinat Epidemiol 2011; 25:388-93. https://doi.org/10.1111/j.1365-3016.2010.01180.x
7. Dinleyici EC, Kurugol Z, Turel O, et al. Epidemiology and economic impact of varisella-related hospitalizations in Turkey from 2008 to 2010: a nationwide survey during the pre-vaccine era (VARICOMP study). Eur $J$ Pediatr 2012; 171:817-25. https://doi.org/10.1007/s00431-011-1650-z

8. Leung J, Harpaz R, Baughman AL, et al. Evaluation of laboratory methods for diagnosis of varisella. Clin Infect Dis 2010; 51:23-32.

9. Stránská R, Schuurman R, Vos M, Van Loon AM. Routine use of a highly automated and internally controlled real-time PCR assay for the diagnosis of herpes simplex and varisella-zoster virus infections. $J$ Clin Virol 2004; 30:39-44. https://doi.org/10.1016/j.jcv.2003.08.006

10. Sauerbrei A. Diagnosis, antiviral therapy, and prophylaxis of varisella-zoster virus infections. Eur J Clin Microbiol Infect Dis 2016; 35:723-34. https://doi.org/10.1007/s10096-016-2605-0

11. Sauerbrei A. Varisella-zoster virus infections during pregnancy. In: Mushahwar K (ed) Congenital and other related infectious diseases of the newborn. Perspectives in Medical Virology, vol 13. Elsevier, Amsterdam, 2007; 51-73.

12. Weinmann S, Chun C, Mullooly JP, et al. Laboratory diagnosis and characteristics of breakthrough varisella in children. J Infect Dis 2008; 197(Suppl 2):S132-8.

13. Kneitz RH, Schubert J, Tollmann F, ZensW, Hedman $\mathbf{K}$, Weissbrich B. A new method for determination of varisella-zoster virüs immunoglobulin $G$ avidity in serum and cerebrospinal fluid. BMC Infect Dis 2004; $4: 33$. https://doi.org/10.1186/1471-2334-4-33

14. Lope A, Schmid S, Stephanie Bialek S. VPD Surveillance Manual, CDC Manual for the Surveillance of Vaccine-Preventable Diseases, $5^{\text {th }}$ Ed., 2011.

15. Köse Ü, ÖzgÜven AA, Ecemiş T, Akçalı S, Lağarlı T, Onağ A. Manisa ilinde yaşayan 7-15 yaş grubundaki çocuklarda suçiçeği seroprevalansı. Ege Tip Derg 2011; 50:187-91.

16. Dilli D, Dallar Y, Önde U, Doğan F, Yağcı S. Ergenlerde kızamık, kızamıkçık, kabakulak ve suçiçeği seroprevalansı. Çocuk Derg 2008; 8:172-8.

17. Türkmen M, Buğdaycı R, Sönmez M. 0-12 yaş çocuklarda suçiçeği enfeksiyonu geçirme sıklığı. Çukurova Univ Tip Fak Derg 2001; 26:137-41. 